\title{
Interpreted Regional Seismic Reflection Lines, National Petroleum Reserve in Alaska
}

By Christopher S. Kulander ${ }^{1}$, John A. Grow ${ }^{2}$, Christopher J. Potter ${ }^{2}$, Richard W. Saltus ${ }^{2}$, and Michele L. Killgore

1 Independent Contractor, MS 939, Denver Federal Center, Denver, C0 80225

2 U.S. Geological Survey, MS 939, Denver Federal Center, Denver, CO 80225

Open-File Report 2005-1402 


\section{U.S. Department of the Interior \\ Gale A. Norton, Secretary \\ U.S. Geological Survey \\ P. Patrick Leahy, Acting Director}

U.S. Geological Survey, Menlo Park, California: 2005

For more information about the USGS and its products:

Telephone: 1-888-ASK-USGS

World Wide Web: http://www.usgs.gov/

Any use of trade, product, or firm names in this publication is for descriptive purposes only and does not imply endorsement by the U.S. Government.

Although this report is in the public domain, permission must be secured from the individual copyright owners to reproduce any copyrighted materials contained within this report. 


\section{Contents}

Abstract

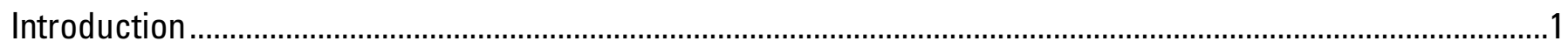

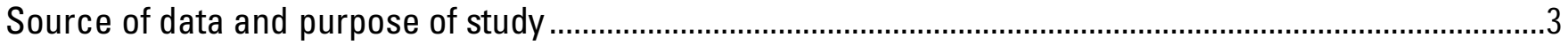

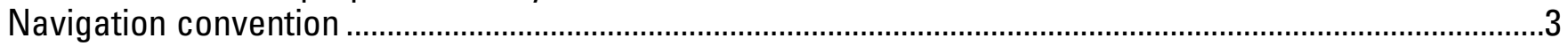

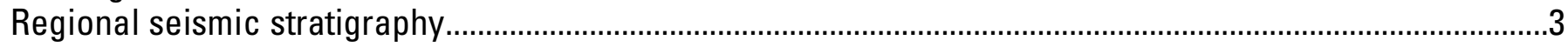

Seismic horizon interpretations in the NPRA ………………..........................................................

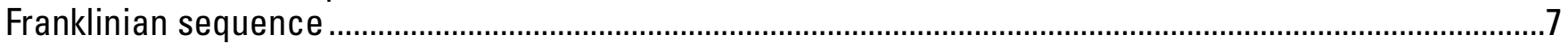

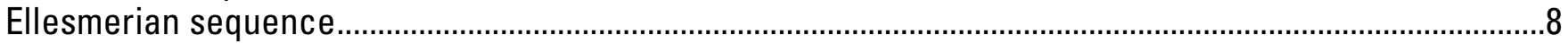

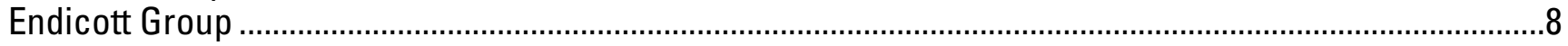

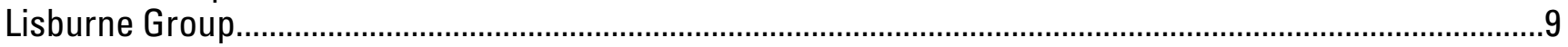

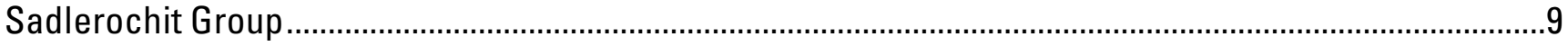

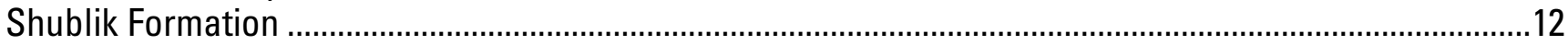

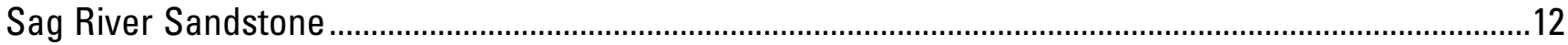

Beaufortian sequence

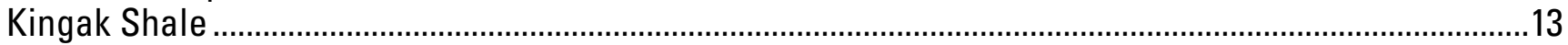

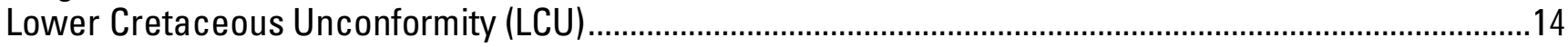

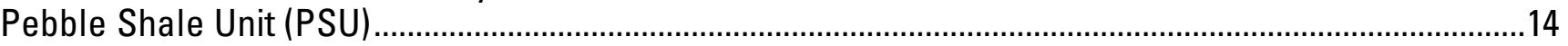

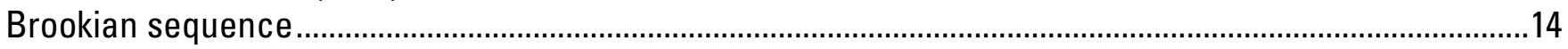

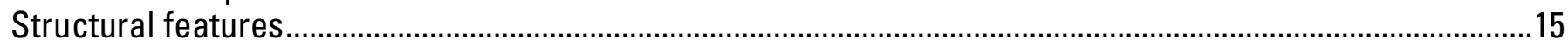

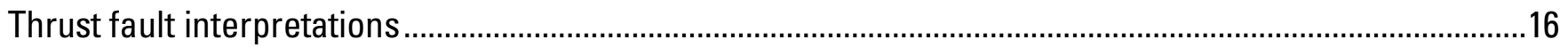

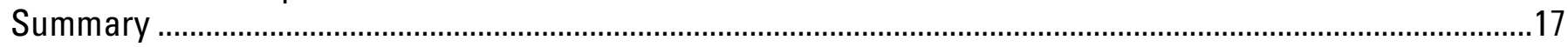

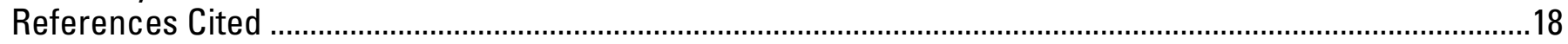

\section{Figures}

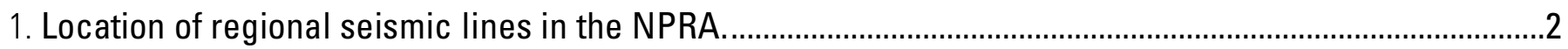

2. Generalized stratigraphy of the NPRA. ……….............................................................................

3. Synthetic seismogram from the Kuyanak well. ………………………………………………………....

4. Synthetic seismogram from the Peard well.............................................................................................

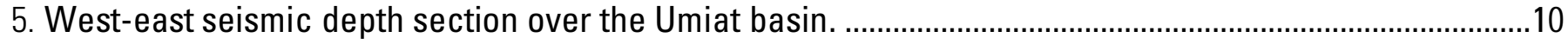

6. North-south seismic depth section over the Umiat basin. …………………………………........................11

\section{Plates}

1. Line R-1 interpreted seismic section.

2. Line R-1alt interpreted seismic section

3. Line R-2 interpreted seismic section

4. Line R-3 interpreted seismic section

5. Line R-4 interpreted seismic section

6. Line R-5 interpreted seismic section

7. Line R-6 interpreted seismic section

8. Line R-7 interpreted seismic section

9. Line R-8 interpreted seismic section

10. Line R-9 interpreted seismic section

11. Line R-10 interpreted seismic section

12. Line R-11 interpreted seismic section

13. Line R-12 interpreted seismic section 
14. Line R-13 interpreted seismic section

15. Line R-14 interpreted seismic section

16. Line R-15 interpreted seismic section

17. Line R-16 interpreted seismic section

18. Line R-17 interpreted seismic section

19. Line $R-18$ interpreted seismic section

20. Line R-19 interpreted seismic section

21. Line $R-20$ interpreted seismic section

22. Line R-21 interpreted seismic section

23. Line R-22 interpreted seismic section

24. Line R-23 interpreted seismic section

25. Line R-24 interpreted seismic section

\section{Conversion Factors}

\section{Inch/Pound to SI}

\begin{tabular}{lll}
\hline \multicolumn{1}{c}{ Multiply } & \multicolumn{1}{c}{ By } & \multicolumn{1}{c}{ To obtain } \\
\hline Length & & \\
\hline foot (ft) & 0.3048 & meter $(\mathrm{m})$ \\
mile (mi) & 1.609 & kilometer $(\mathrm{km})$ \\
mile, nautical (nmi) & 1.852 & kilometer $(\mathrm{km})$ \\
yard (yd) & 0.9144 & meter $(\mathrm{m})$ \\
\hline
\end{tabular}




\title{
Interpreted Regional Seismic Reflection Lines, National Petroleum Reserve in Alaska
}

\author{
by Kulander, C.S. ${ }^{1}$, Grow, J.A. ${ }^{2}$, Potter, C.J. ${ }^{2}$, Saltus, R.W. ${ }^{2}$, and Killgore, M.L. ${ }^{1}$
}

\section{Abstract}

Interpretation of reprocessed data from a regional grid of 25 public-domain 2-D seismic profiles in the National Petroleum Reserve in Alaska has enabled an analysis of subsurface geologic relations throughout that region. Notable results include interpretations of the geometry of the Mississippian Umiat and Meade basins, and depositional patterns in the thick succession of younger strata that were influenced by major structural features such as the Barrow arch and the Brooks Range.

Pre-Mississippian low-grade metamorphic rocks and subordinate granites of the Franklinian sequence are the basement rocks of the region. The top of the Franklinian is imaged as one of the highest amplitude, most continuous reflections.

The sedimentary succession includes (1) the Mississippian to Triassic Ellesmerian sequence (consisting of the Endicott, Lisburne and Sadlerochit groups, and the Shublik Formation and Sag River Sandstone; (2) the Beaufortian sequence, comprising the Jurassic to Lower Cretaceous Kingak Shale and the overlying Lower Cretaceous pebble shale unit; and (3) the Cretaceous to Paleocene Brookian sequence, which includes the Hue Shale and the Torok, Nanushuk, Seabee, Tuluvak, Schrader Bluff, and Prince Creek formations.

Stratigraphic horizons that were mapped seismically include the tops of the Franklinian basement, the Endicott, Lisburne, and Sadlerochit groups, the Shublik Formation, the Sag River Sandstone, the Lower Cretaceous unconformity (LCU), and the gamma-ray zone of the Hue Shale. Distinguishing criteria were established for the seismic-reflection characteristics for each of these horizons, and the results were used in the correlation of units across the basins and onto the bordering margins.

\section{Introduction}

We present interpretations of 25 two-dimensional regional seismic transects (fig. 1) across the National Petroleum Reserve in Alaska (NPRA). These seismic lines, totaling 3470 line-miles, include the 20 original Regional Compressed Sections (RCS) of Ikleman (1986), reprocessed by Miller and others (2000), plus 5 additional reprocessed regional lines (Miller and others, 2001). The complete NPRA seismic data set totals nearly 15,000 miles (Gryc, 1985) and is the largest public-domain onshore seismic database in the United States. The 25 regional seismic lines presented here provide a useful summary, and the interpretations provide an aid for understanding the overall geologic framework of the Brooks Range foreland basin and for assisting research studies concerning the oil and gas potential of the region. 


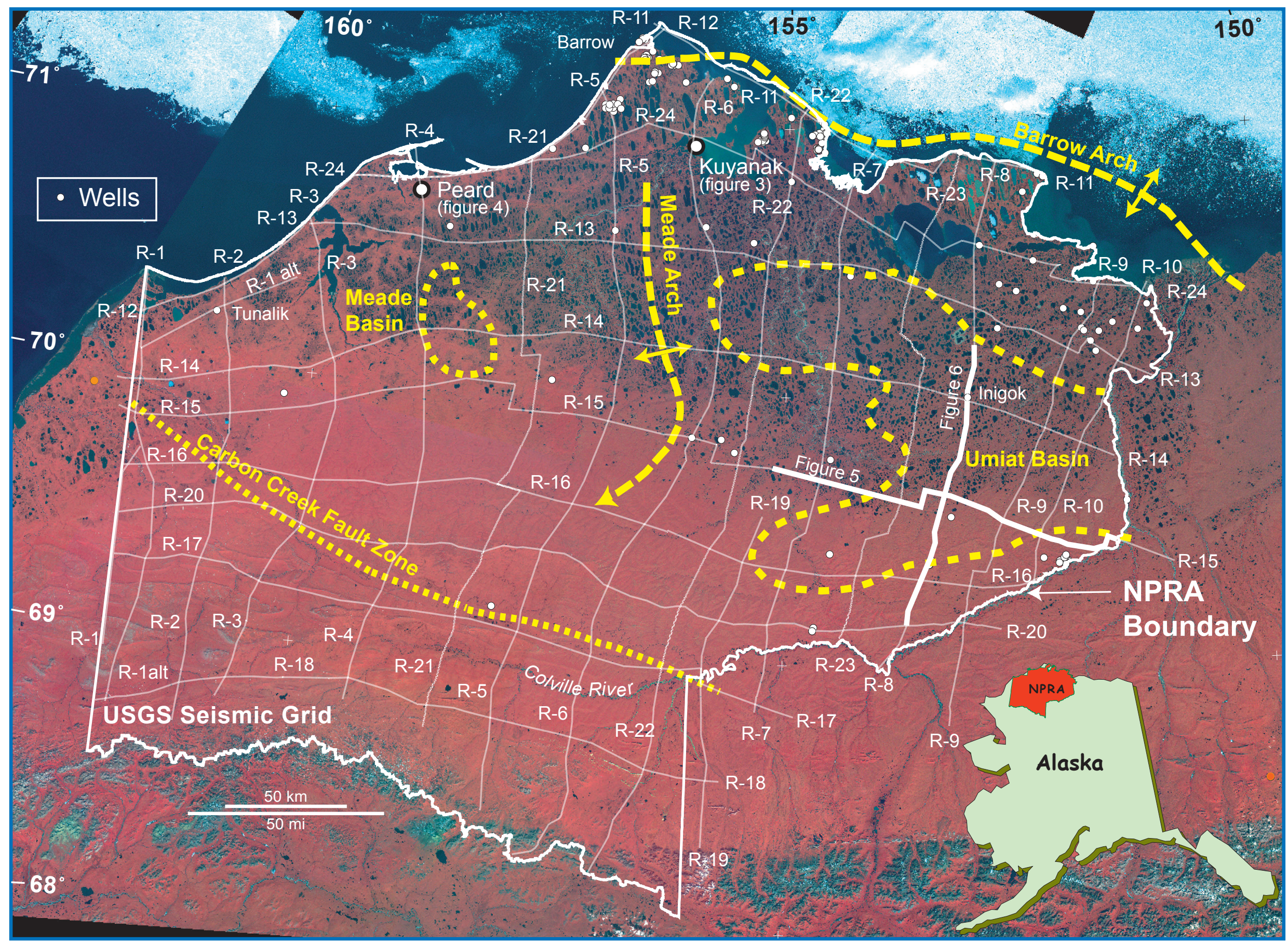

Figure 1. Location of regional seismic lines (white) and selected subsurface features (yellow) within the NPRA plotted on LANDSAT satellite image. Geologic features are after Kirschner and Rycerski (1988) who used the full suite of NPRA 2D seismic in their determination. 


\section{Sources of Data and Purpose of Study}

The original RCS seismic grid (Ikelman, 1986) combined selected seismic lines into 20 long regional lines that covered all of NPRA in a nominal $20 \times 20$-mile grid. Five additional lines were added later by the USGS, so that the regional grid now consists of 25 lines. Fifteen lines are oriented generally north-south and ten lines are oriented generally east-west (fig. 1). The seismic lines that composed each of the original RCS lines were the stacked, unmigrated, record sections that were originally processed by Geophysical Service, Incorporated (GSI) immediately after the data were collected (1974 through 1981). Later, these were reprocessed (including migration) and published as digital files by Miller and others (2000, 2001). Uninterpreted, reprocessed seismic data (SEG-Y format), along with the corresponding navigational files (SEG-P1 format) for all of the lines interpreted in this report are available in Miller and others (2000, 2001).

The purpose of this study was to interpret the tops of eight key stratigraphic horizons on each of the 25 seismic profiles plotted in two-way travel time (Plates 1-25). These are Adobe Acrobat ${ }^{\circledR}$ PDF displays of the seismic reflection lines with the formation tops and selected faults shown. The tops are color coded, with each horizon given a color consistent with a color key on each line. Mapped horizons include the tops of the Franklinian basement, the Endicott, Lisburne, and Sadlerochit groups, the Shublik Formation, the Sag River Sandstone, the Lower Cretaceous unconformity (LCU) and the gamma-ray zone (GRZ) of the Hue Shale (fig. 2). Synthetic seismograms constructed from digital well logs of 30 wells located primarily close to the coast or to the Colville River were used to correlate formation tops in wells to their respective seismic horizons. Examples of two synthetic seismograms tied to adjacent seismic lines are shown in figures 3 and 4.

\section{Navigation Convention}

Interactive seismic interpretation software requires a unique index number to relate each seismic trace in a line to a surface position on a map. Further, migration algorithms assume that for each seismic line, the distance between consecutive traces is at some regular, constant interval. Miller and others $(2000,2001)$ reprocessed the data to meet this requirement by resequencing the seismic traces at a constant distance of $110 \mathrm{ft}$. The renumbered traces are shown in the header of each seismic trace as the Common Depth Point (CDP) numbers which are also used as the index number for the navigation data. Users loading these data into their own interpretation workstation should consider the unique CDP number to be the "shotpoint" number.

\section{Regional Seismic Stratigraphy}

The regional stratigraphy of the North Slope is divided into four first-order depositional sequences (fig. 2), each related to major tectonic phases in the evolution of northern Alaska. The stratigraphically lowest is the Franklinian sequence, which consists of mildly metamorphosed preMississippian rocks. The overlying Ellesmerian sequence comprises Mississippian through Triassic carbonate and siliciclastic deposits that accumulated on a south-facing (present-day orientation), passive continental margin. The Beaufortian sequence consists primarily of Early Jurassic through Early Cretaceous (Barremian) clastic deposits that record erosional and depositional effects of rifting associated with the opening of the Canada basin. The Beaufortian sequence is characterized 


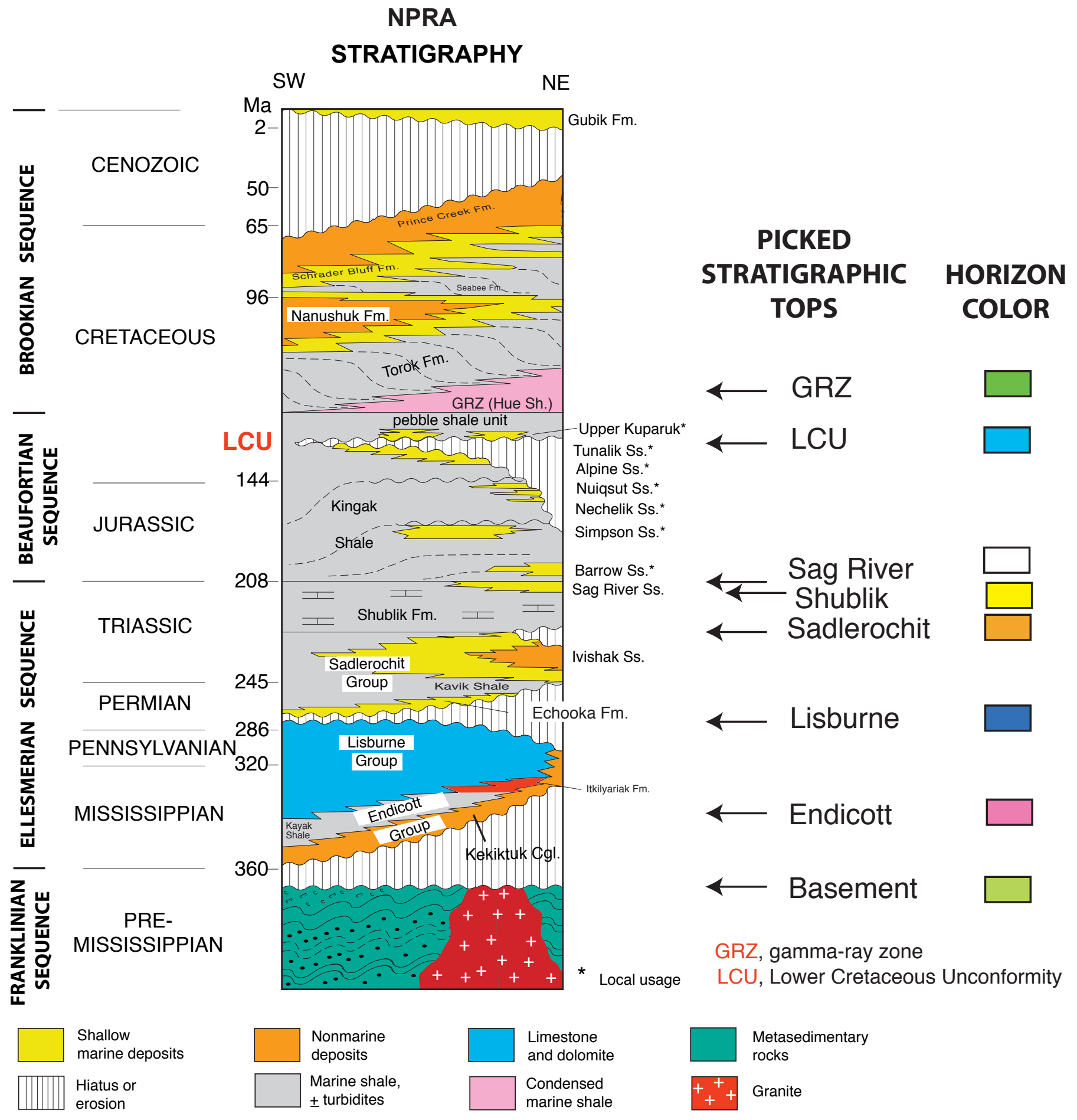

Figure 2. Generalized stratigraphy of the NPRA (modified from Bird and Houseknecht, 2002) showing the eight horizons mapped on the regional seismic sections. 


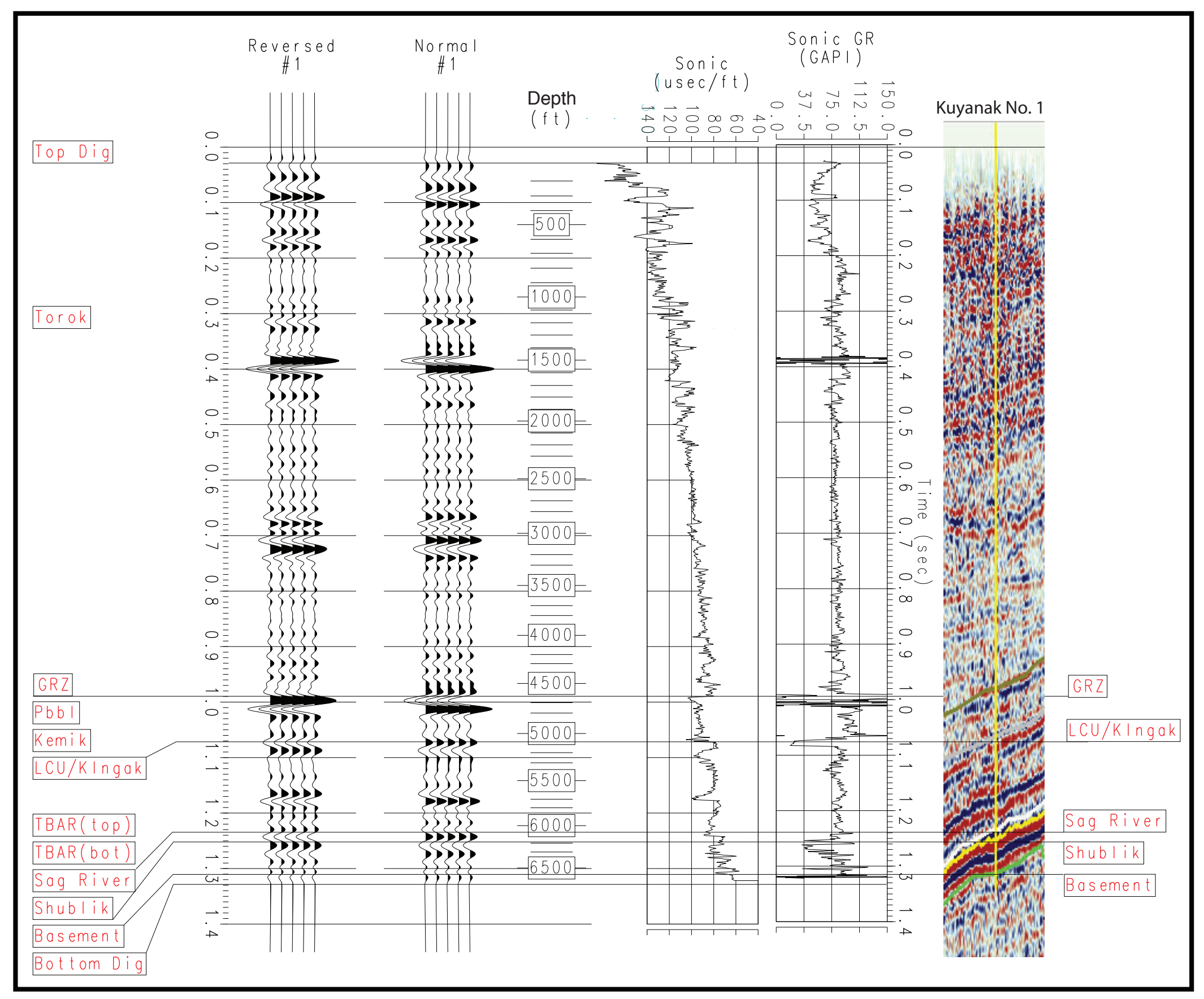

Figure 3. Correlation of synthetic seismogram from the Kuyanak well to a portion of seismic line R-6. See figure 1 for location. 


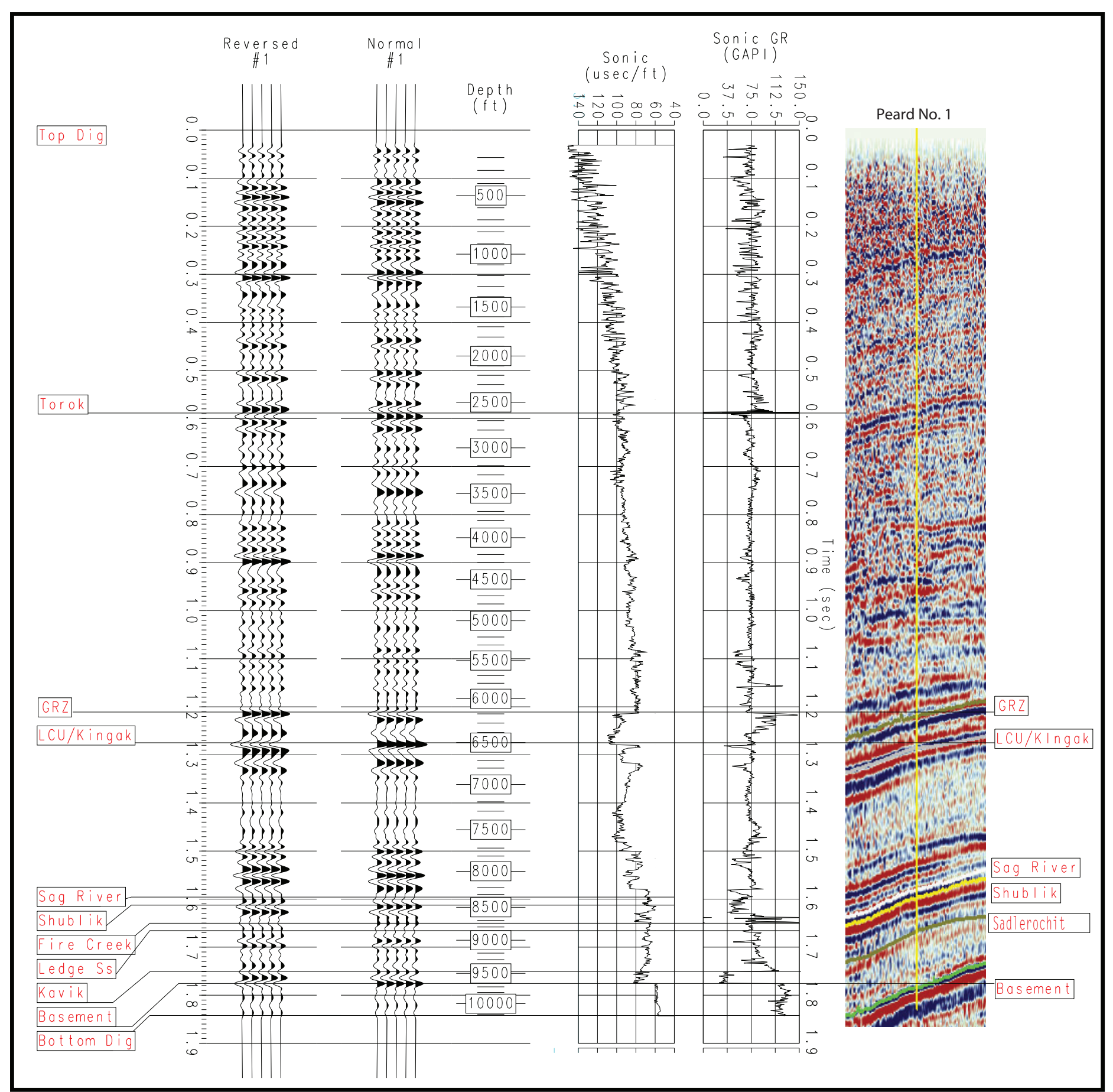

Figure 4. Correlation of the synthetic seismogram from the Peard well to a portion of seismic line R-4. See figure 1 for location. 
by southward prograding clinoforms (mostly in the Kingak Shale, fig. 2) that indicate southward to southeastward offlap (Houseknecht, 2001). This progradation is most easily seen on the north-south R-8 and R-9 seismic lines (plates 9 and 10). The Brookian sequence consists of Lower Cretaceous through Lower Tertiary strata. These strata are primarily siliciclastic foreland basin deposits that were shed northward from the Brooks Range orogen, which lies mainly to the south of NPRA. The Brookian is distinguished by a northward progradation and seismically defined clinoforms that indicate northward to northeastward offlap (Molenaar, 1988; Moore and others, 1994).

Two synthetic seismograms constructed from well log data from the Kuyanak and Peard wells have been placed next to seismic-reflection interpretations in figures 3 and 4 . There is strong correlation between the well log data and the seismic data, especially in the interval below the gamma-ray zone (GRZ) of the Hue Shale. This is typical of the study area.

\section{Seismic Horizon Interpretation in the NPRA}

Horizons were picked according to criteria unique to each formation or unconformity, but several overall standards and procedures can be described for all.

1) Stratigraphic picks in well logs,tied to synthetic seismograms where available,provide the best chance to tie specific reflections to formation tops. Thus, in the northern, northeastern, and eastern parts of the NPRA where well coverage is best, seismic picks between wells can be compared, resulting in more closely constrained interpretations. In areas of sparse well coverage, such as near the Peard, Inigok, and Kuyanak wells, the interpreted synthetic seismogram provides a preliminary pick that can be expanded along the nearby seismic lines. The reliable interpretations provided locally by these individual wells were carried, as well as possible, to areas of no well coverage.

2) Certain strong lithologic contrasts will almost certainly be associated with strong reflections. For example, the carbonates of the Lisburne can be expected to provide a strong positive reflection when contrasted to the clastic strata above.

3) Where zones of poor data quality were encountered, reliable picks from the nearest control points were projected as far as was feasible before applying a simple "best fit" to bridge the gap.

4) Regional zones of poor data quality, such as the Ellesmerian south of line R-20, were left uninterpreted.

\section{Franklinian Sequence}

The Franklinian sequence comprises pre-Mississippian low-grade metamorphic rocks and minor intrusions of granite (fig. 2). Few wells penetrate these rocks south of the Barrow arch (fig. 1). Moore and others (1994) noted phyllites and argillites with slaty cleavage, small-scale faults, and isoclinal folds both in core and outcrop. Dipmeter and drill cores indicate locally steep dips in the pre-Mississippian strata beneath the coastal plain. The reprocessed seismic data used in this study clearly show broad regions with steeply dipping intra-basement reflections at a number of places across the NPRA. For example, the top of the pre-Mississippian basement is an angular 
unconformity on line R-5 (pl. 6) near the Barrow arch, and produces a strong reflection throughout much of the northern NPRA.

The seismic character of the pre-Mississippian rocks is very intermittent yet strongly reflective in the northern NPRA. A combination of velocity effects from younger basins, structures associated with the Brooks Range to the south, and time/depth limits of the seismic data set tend to obscure both internal characteristics and thicknesses of pre-Mississippian rock units to the south. Typically, internal features of the basement are visible only in local areas. In a number of areas, particularly in the north along the longer east-west lines (for example, lines R-13 andR-24 shown in plates 14 and 25), stray intra-basement reflections display steep dips that are largely independent of dip of the overlying strata (so they are not multiples). Below areas of strong Ellesmerian reflections, basement reflections are commonly overprinted by strong multiples. These overprints are particularly evident on the longer east-west lines over the Meade arch (line R-24 in pl. 25) and in the Umiat and Meade basins (lines R-8 and R-14, respectively; pls. 9 and 15; fig. 1). Along the Barrow arch (lines R-11, R-12 in pls. 12 and 13)), where the Franklinian sequence is closer to the surface, a strongly angular basement-top unconformity is well defined and truncates strong, fairly continuous intra-basement reflectors. Franklinian rocks have been cored over the Barrow arch. Moore and others (1994) noted that fine-grained Silurian and Ordovician rocks are widespread to the north and Brosgé and others (1962) described gray phyllite and argillite interspersed with dolomite.

The amplitude of the reflection at the top of the Franklinian sequence changes according to the acoustic impedance relationship between the strata above and below the unconformity. The amplitude, and sometimes even the polarity, of the basement reflection changes laterally because the lithologic variation within the pre-Mississippian strata, such as on line R-12 (pl. 13) along the Barrow arch (fig. 1). The basement reflection changes polarity laterally on almost all of the seismic lines. Generally, however, the pre-Mississippian rocks are considerably denser than the Ellesmerian section that overlies them, making the top of pre-Mississippian basement one of the highest amplitude, most continuous reflections in the NPRA. However, in places where basement is very deep, such as in the center of the Umiat basin (fig. 1) where basement depth reaches 30,000 ft below sea level, it is difficult to interpret accurately.

\section{Ellesmerian Sequence}

The Mississippian to Triassic Ellesmerian sequence, including the Endicott, Lisburne, and Sadlerochit groups, Shublik Formation, and the Sag River Sandstone is composed of northerlyderived sedimentary rocks inferred to have been deposited on a south-facing continental margin. Thickest along a broad east-west trend between the Barrow arch and the Brooks Range foothills, the Ellesmerian represents a transition from non-marine clastic rocks (Endicott Group) to marine limestone (Lisburne Group) and marine Shublik and Sag River Sandstone. The Ellesmerian sequence contains an important internal unconformity, found throughout the NPRA, which marks a depositional hiatus between the carbonate rocks of the Lisburne Group and the fine-grained shallow marine clastic deposits commonly found at the base of the Sadlerochit Group.

\section{Endicott Group}

The Endicott Group, primarily of Mississippian age, ranges from 0 to $10,000 \mathrm{ft}$ in thickness, with the variations depending largely on basement structure. The thickest sections are therefore found in structural depressions that developed during Mississippian time, such as Umiat and Meade 
basins (fig. 1). It is absent over the Meade and Barrow arches [lines R-14 and R-11 respectively (pls. 15, 12; fig. 1)], owing to onlap and erosional truncation. In the thickest sections, the Endicott Group is divided into the Kekiktuk Conglomerate and the Kayak Shale (fig. 2). The sequence becomes younger towards the north in the NPRA, where Bird (1988a) noted that it is possibly as young as the earliest Permian. Armstrong and Bird (1976) proposed that the nearshore and nonmarine clastic rocks were deposited on an extensive shallow marine platform north of the carbonates of the Lisburne Group.

The top of the Endicott Group generates a fairly high amplitude reflection throughout the NPRA. Depth converted seismic lines show that more than 9,000 ft of strata are present in the deepest part of the Umiat basin (figs. 5,6). An example of the seismic character of the Endicott and Lisburne is shown in Figure 5. The acoustic contrast between the lower Endicott and the preMississippian basement is low, making them seismically indistinguishable in many places, especially on north-south seismic sections. Onlapping surface truncations are present on northsouth sections, however, and these are useful in marking the upper surface of the pre-Mississippian basement.

\section{Lisburne Group}

The Lisburne Group is a widespread unit that consists primarily of massive, light-gray limestone and dolomite. Some lower horizons contain gray dolomite and black to dark-gray nodular chert. It is Mississippian in the northern foothills of the Brooks Range (lines R-18, R-17 shown in plates 19,18) and the south ends of the north-south lines), and as young as Permian in the north along the Arctic coastline. In the region around the Endicott basins, the Lisburne carbonates include late Mississippian to early Permian strata and thicken to more than 6,000 ft.

The Lisburne Group has been subdivided into three or more formations that, in general, are similar lithologically, hence are difficult to differentiate in many places (Brosgé and others, 1962; Campbell, 1967; Bird 1988a). The upper boundary of the Lisburne Group is a conspicuous, laterally continuous positive-amplitude reflection where the calcareous sandstone and siltstone of the Echooka Formation of the Sadlerochit Group rests on carbonate rocks of the Lisburne Group. Internally, the Lisburne's reflections are continuous, low and medium amplitude reflections that expand and converge rather than onlap or downlap on one another or display prominent reflection truncations against fault boundaries. This suggests the Lisburne's thickening in the Mississippian basins is more a result of compaction of older sediments than filling of accommodation space created by faulting. However, the base of the Lisburne is locally cut by basin-bounding faults, so some accommodation space had to have been generated during deposition.

\section{Sadlerochit Group}

The Permian and Early Triassic Sadlerochit Group is an extensive unit composed of nonmarine and upper-shelf deposits. Along the Barrow arch, it consists primarily of nonmarine conglomerate and fine-grained marine and non-marine sandstone and siltstone, which becomes finer grained and more marine in character further south. The Sadlerochit Group is the oldest unit whose thickness is largely unaffected by the lower Ellesmerian subsidence recorded in the Umiat basin. 


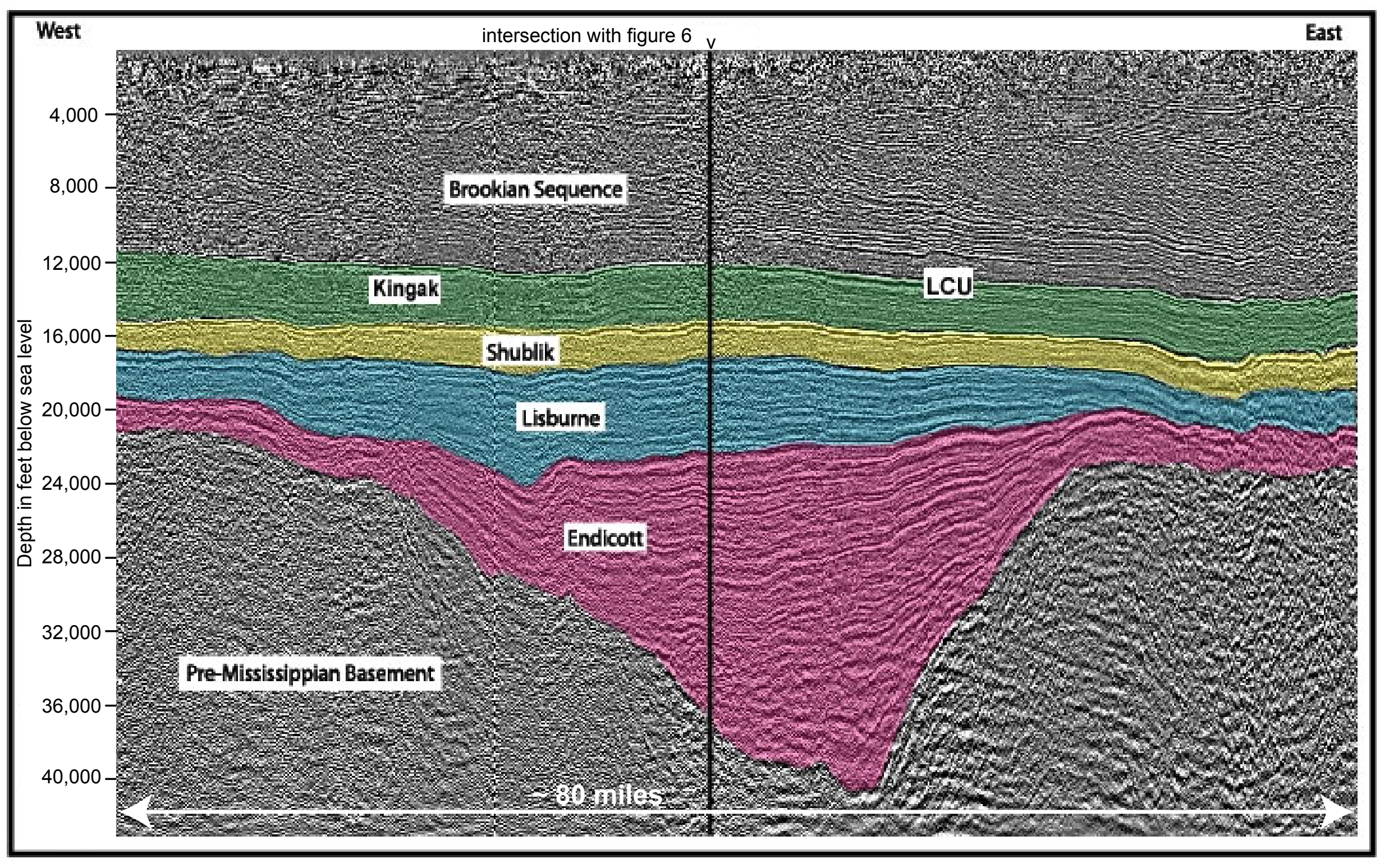

Figure 5. West-east seismic depth section over the Umiat basin (line R-15). See figure 1 for location. 


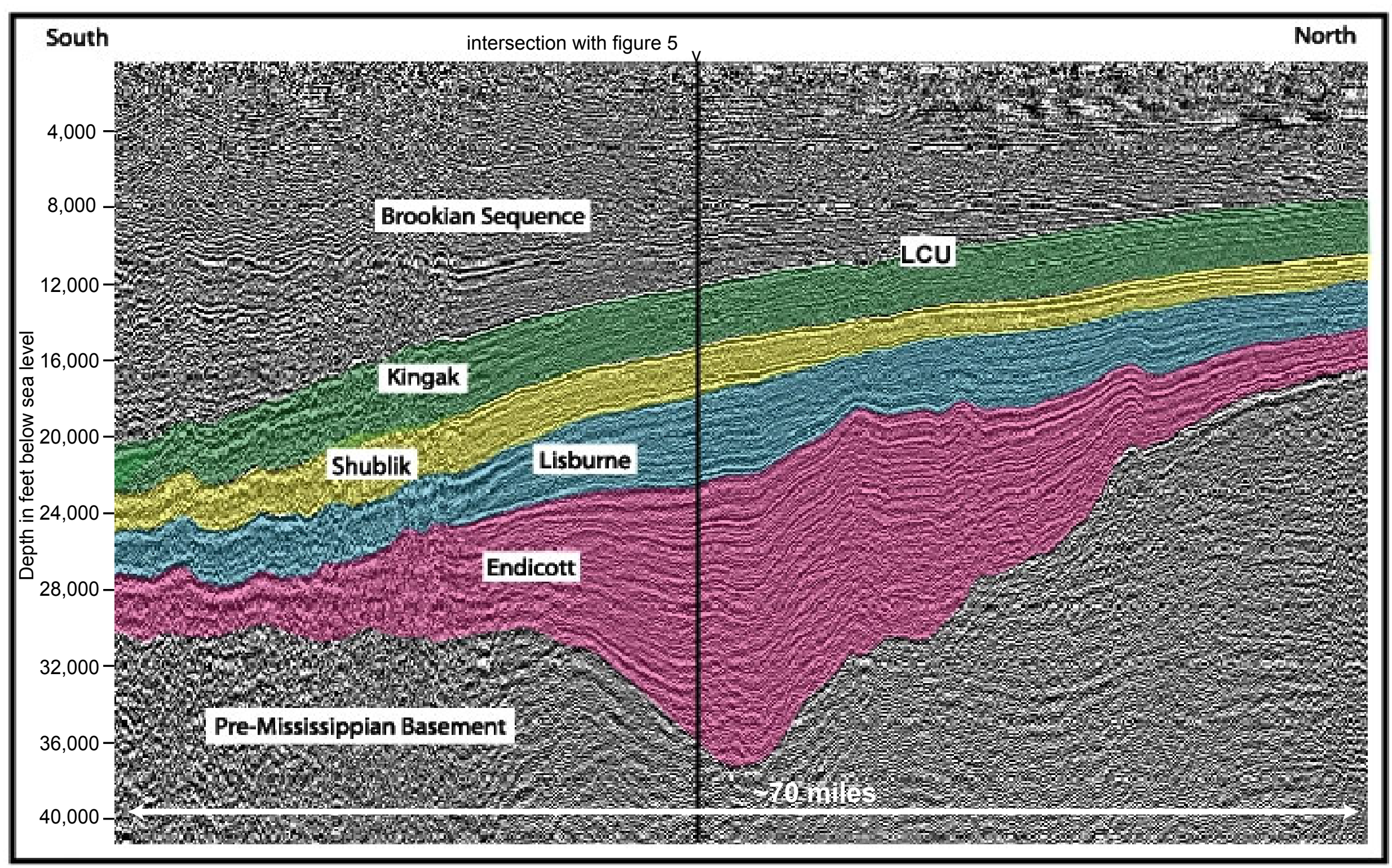

figure 6. North-south seismic depth secttion over the Umiat basin (line R-8). See figure 1 for location. 
In the Inigok well (fig. 1), the thickness of the Sadlerochit Group is slightly more than 1,500 ft. Regionally there is a gradual thinning north of the Umiat basin (north end of line R-8) before being truncated by the Lower Cretaceous unconformity (LCU). The Sadlerochit contains two formations, the Echooka and the Ivishak. The Echooka Formation is a Permian calcareous sandstone, mudstone and silty limestone deposited over the Lisburne Group carbonates. Crowder (1990) noted a chert conglomerate at the base of the Echooka in northeast Brooks Range exposures more than 100 miles east of NPRA which may explain some variation in amplitudes of internal reflections within the Sadlerochit most easily seen on north-south lines. For example, line R-8 (pl. 9) around shot point 3400 shows an abrupt increase in amplitude in the middle of the Sadlerochit, possibly caused by the presence of a thick chert conglomerate. The Permian and Triassic Ivishak Formation consists of clastic rocks of varying grain size deposited in both marine and non-marine settings (Keller and others, 1961; Moore and others, 1994). The Kavik Shale Member (fig. 2) represents the lowest part of the Ivishak Formation and consists of over $350 \mathrm{ft}$ of dark gray laminated shale and siltstone in the Inigok well. Toward the Barrow arch, the Kavik Member thins.

As the Peard synthetic seismogram illustrates (fig. 4), the acoustic contrast between the overlying Shublik Formation and the Sadlerochit Group is generally low, making it difficult to identify the contact between the two formations based on seismic data.

\section{Shublik Formation}

Described by Mull and others (1987) as a dark gray and richly fossiliferous shale with bioturbated mudstone, dolomite, and bioclastic limestone, the Triassic Shublik Formation ranges in thickness from $300 \mathrm{ft}$ to a maximum of about $600 \mathrm{ft}$ over the Umiat basin. Moore and others (1994) noted the possibility of slightly greater thicknesses near Point Barrow, but the reflection data in that area are characterized by such low resolution that most of the post-Franklinian sediments cannot be resolved. The Shublik onlaps the Franklinian rocks approaching the apex of the Barrow arch, north of which it is truncated by the Lower Cretaceous unconformity.

The upper boundaries of the Shublik Formation and the overlying Sag River Sandstone both produce strong positive reflections throughout the NPRA. Because the Sag River Sandstone is thin, reflections from the top and bottom of the unit commonly interfere with one another, making it difficult to resolve the thickness of the Shublik in seismic data. This is particularly evident where interference from thick overlying Brookian sediments lowers resolution (for example, lines R-5 and R-6 shown in plates 6 and 7).

The Shublik's upper boundary is masked on places by destructive interference from highamplitude downlapping reflections in the Beaufortian Kingak Shale. Not only does this make picking the exact top of the Ellesmerian sequence very speculative in places, but it prevents recognizing the thin interval between the Sag River and the Shublik impossible. In these cases, the Shublik and Sag River horizons were arbitrarily picked parallel to one another with only a couple of milliseconds interval in between.

\section{Sag River Sandstone}

The uppermost Triassic to Lower Jurassic Sag River Sandstone (Barnes, 2001) is $30 \mathrm{ft}$ thick in the Inigok well and remains thin over most of the NPRA. It is inferred to be less than $50 \mathrm{ft}$ thick or absent across southern NPRA, where Moore and others (1994) and Houseknecht (2001) noted 
that the Kingak Shale lies directly on the Shublik Formation. When present and resolvable, it is a strong positive reflection; in some places it disappears in interference caused by downlapping sequences in the younger Kingak Shale. Nearly every line contains zones where these highamplitude downlapping reflections from the Kingak Shale make it impossible to differentiate the top of the thin Sag River from the top of the Shublik. In such cases, the top of the Sag River was picked where the downlapping Kingak reflections terminate. The termination points of these reflections were then connected to define the top of the Sag River. Typically, in such cases, the top of the Shublik was obscured as well.

Across northern NPRA south of the Barrow arch, the Sag River Sandstone lies beneath the Kingak Shale (Bird, 1988b), and is present in the two southernmost penetrations (Tunalik and Inigok) of the base of the Kingak. The Sag River Sandstone is interpreted as truncating along a line that roughly trends east-west between lines R-14 and R-15 (fig. 1). On seismic data, the exact point of the Sag River Sandstone pinchout can be difficult to pinpoint. On lines such as R-4 (pl. 5), the Sag River Sandstone truncation point is picked where the highest positive amplitude that is consistently parallel to-and one or two cycles above -the Shublik appears to gradually truncate into the top of the Shublik.

\section{Beaufortian Sequence}

\section{Kingak Shale}

The Kingak Shale is a thick black to dark gray noncalcareous shale and siltstone that overlies the much thinner Sag River Sandstone (fig. 2). Near the Umiat basin (fig. 1), the base of the Kingak Shale is generally Sag River strata. On the Barrow peninsula, both the Shublik Formation and the Sag River Sandstone pinch out northward and the Kingak Shale lies directly on preMississippian argillite (Bird, 1987). A high amplitude seismic reflection corresponding to the top of the Shublik is used to define the base of the Kingak Shale throughout the NPRA for purposes of correlation and mapping. Where the underlying Sag River or Shublik tops are indistinct, the bottom of the Kingak Shale is picked at the termination points of the basal, downlapping reflections.

Houseknecht (2001) noted four separate stratigraphic sequences in the Kingak Shale, and distinguished each of these on some of the regional seismic lines. With the exception of the southernmost NPRA (south of line R-20), we found these sequences to be visible throughout the dataset. Within some of the Kingak Shale sequences, the data are nearly transparent, with the only continuous intra-Kingak Shale reflections coming from the sequence boundaries (for example, see the lowermost sequence on line R-8 (pl. 9) around shot point 3900).

Seismic data indicate a maximum Kingak thickness of about 4,000 ft in the central NPRA (Bird, 1988b). Although beveled by the LCU, the upper Kingak strata are inferred to be present in the subsurface throughout southern NPRA. No complete penetrations of the Kingak have been made south of the Tunalik and Inigok wells.

The top of the Kingak Shale corresponds to the LCU and the base of the pebble shale unit throughout most of the NPRA. Sandstones of limited extent, such as Tunalik sandstone are also locally present at the top of the Kingak beneath the LCU. In areas of poor seismic data quality, particularly near the Barrow arch and further south in the foothills fold belt, the top of the Kingak/LCU commonly provides one of the few reflectors in the Beaufortian and Brookian sequences. Beneath the Brooks Range foothills, this reflection is imbricated by thrusts that splay upwards from a regional detachment in the Kingak. 


\section{Lower Cretaceous Unconformity (LCU)}

The Lower Cretaceous unconformity (LCU) and overlying pebble shale mark the transition between the Beaufortian sequence and the overlying Brookian sequence, two regimes with opposing sedimentation directions. The LCU is directly overlain by the thin pebble shale unit (described below). In places where the pebble shale is seismically unresolvable, the LCU is distinguished by the north-dipping downlapping reflections of the Brookian Torok Formation above, and the gradual truncation of the Kingak below it.

Unlike reflections that commonly define formation tops, the LCU is not a continuous reflector, but rather is the locus of the alternating positive and negative interference caused by reflections downlapping onto the continuous negative-polarity reflection at the top of the Kingak Shale. Along the Barrow arch (line R-11 and R-12), for example, the polarity of the LCU reflection changes several times, and the LCU is picked on the basis of terminations of the downlapping reflections. Due to the LCU's relatively shallow depth, it is penetrated by numerous wells.

In the southern part of the NPRA, there is a gradual north to south change in the horizon marking the LCU from an unconformity to a correlative conformity as noted by Houseknecht (2001). This change is commonly difficult to observe on the regional seismic lines because of areas of poor seismic imaging (for example, the Foothills belt) and locally strong destructive interference of seismic energy.

\section{Pebble Shale Unit}

The pebble shale unit, directly overlying the LCU, is inferred to be the uppermost unit of the northerly-derived Beaufortian sequence. The pebble shale is a thin (commonly $<300 \mathrm{ft}$ ) but distinctive unit of black, organic rich marine shale supporting large, rounded pebbles and sand of quartz and chert (Mull and others, 1987). Bird (1987) reported thicknesses of the pebble shale unit to range from 180 to $500 \mathrm{ft}$, gradually increasing towards Barrow; at the Inigok well, it is $220 \mathrm{ft}$ thick.

On seismic reflection data, the pebble shale unit is imaged as a strong negative-polarity reflection just above the LCU. South of the Umiat basin, the pebble shale unit becomes largely unidentifiable on seismic profiles because of seismic imaging problems caused by the overlying compressed and distorted Brookian deposits. In such cases, the pebble shale unit is mapped as a thin seismic unit on top of the LCU. Where the downlapping Brookian (Torok Formation) reflections have higher amplitudes, the negative-amplitude event marking pebble shale unit cannot be continuously identified. In these cases, the downlapping truncations of the Torok reflections were connected and the resultant horizon was picked as the top of the pebble shale unit.

\section{Brookian Sequence}

Brookian strata, comprising the GRZ (gamma-ray zone) of the Lower Cretaceous Hue Shale, Aptian to Cenomanian Torok Formation, Albian to Cenomanian Nanushuk Formation, Turonian to Coniacian Seabee and Tuluvak Formations, Campanian to Maastrichtian Schrader Bluff Formation, and Campanian to Paleocene Prince Creek Formation (Mull and others, 2003) were not differentiated during the present study, except for the relatively thin GRZ lying immediately above the pebble shale unit (fig. 2). These units generally contain huge volumes of sediment that were eroded from the Brooks Range. The Nanushuk and Torok Formations are 
widely exposed in drainages that cut through the foothills of southern NPRA; the stratigraphically higher formations are exposed in the eastern part of NPRA and are erosionally truncated to the west and south.

On seismic sections, the change in the direction of the sediment source from the Ellesmerian/Beaufortian to the Brookian is striking. Above the pebble shale, the direction of progradation shifts in the opposite direction to that of the Ellesmerian/Beaufortian and clearly progrades northward and eastward. The GRZ (Hue Shale), a condensed section of black shale less than $200 \mathrm{ft}$ thick characterized by an anomalously high gamma-ray signature and a high-amplitude seismic reflection, lies at the base of the Brookian (Molenaar and others, 1987; Bird, 2001). The Torok, directly overlying the GRZ (fig. 2) consists almost entirely of bottomset and foreset (clinoform) seismic reflectors, and the Nanushuk consists of topset seismic reflectors (Houseknecht and Schenk, 2001). The basal 500 to 1,000 feet of the topset facies is also considered part of the Torok Formation, based on the predominance of mudstone over sandstone in this part of the section (Molenaar, 1988). The topset reflections roll over basinward into the clinoforms, indicating the genetic relation between the two (Houseknecht and Schenk, 2001). In the southern part of the NPRA, the lower Torok consists of a northward thinning wedge of sediment that, on east-west seismic lines, can be seen to consist of east-dipping clinoforms that downlap the GRZ (Houseknecht and Schenk, 2001). The Torok is 2,000-3,000 feet thick along the Barrow arch, gradually thickening southward to 5,000 feet, and then abruptly thickening to over 15,000 feet in southern NPRA, whereas the Nanushuk thins from west to east across NPRA, from 8,000 feet in western NPRA to a zero edge just east of NPRA (Houseknecht and Schenk, 2001).

The Brookian is thickest in the southernmost parts of the NPRA, owing mainly to thickening of the lower Torok, along a west-northwest to east-southeast axis that runs roughly parallel to line R-17, R-18, and R-20. Along this belt, it is complexly folded and faulted. The dramatic thickening, combined with the deformation, obscure the underlying Ellesmerian strata.

\section{Structural Features}

North of the Brooks Range foothills, the coastal plain is marked by the gradual attenuation of Ellesmerian strata against the Barrow and Meade arches (fig. 1). The Brookian sequence, in turn, onlaps against the Lower Cretaceous unconformity (LCU), and thins dramatically to the north. Over the Barrow arch, the pre-Mississippian basement rises to within $3000 \mathrm{ft}$ of the surface.

The Barrow arch is a broad structural high trending west-northwest along the Arctic coast (fig. 1). The arch and the hinge-line fault zone that bounds its northern side (offshore) are products of Jurassic to early Cretaceous rifting that formed the oceanic Canada Basin (Grantz and others, 1990; Bird, 2001). Ellesmerian and younger strata thin and drape against pre-Mississippian basement on the south shoulder of the Barrow arch, part of the Arctic platform, a remnant of a south-facing passive margin of Paleozoic and early Mesozoic age (Bird, 2001). Grantz and others (1990) calculated the regional dip of the northern flank of the Barrow arch to be around $12^{\circ}$.

Seismic interpretations south of the arch indicate a shallower dip on the Arctic platform, regionally averaging about $2^{\circ}$ to the south-southwest with steeper local dips reaching $4^{\circ}$. Near Barrow, the top of the Barrow arch reaches its highest point where the top of pre-Mississippian rocks is less than $3000 \mathrm{ft}$ deep (fig. 1). Along the axis of the Barrow arch and on its northern flank, the LCU truncates nearly the entire Beaufortian sequence, placing the pebble shale unit directly on the pre- 
Mississippian sediments. The quality of the seismic data over the shallowest part of the Barrow arch is very poor.

Southward from the Barrow arch into the Colville basin and towards the Brooks Range, each of the Ellesmerian, Beaufortian, and, Brookian sequences thicken considerably, especially the latter. The Torok Formation undergoes the most dramatic thickening, more than tripling in thickness to over $10,500 \mathrm{ft}$ thick in the extreme southern parts of the NPRA. The Nanushuk Group increases in thickness also, nearly doubling in thickness to $3600 \mathrm{ft}$ in the Colville basin.

In contrast to the Brookian sequence, the Ellesmerian and Beaufortian sequences thin south of the Colville River after reaching a maximum thickness along an east-west belt across the middle of the NPRA. Within the Mississippian basins, such as the Umiat and the Meade basins (figs. 5, 6), the Ellesmerian thicknesses increase to $10,000 \mathrm{ft}$. In contrast, the whole Ellesmerian/Beaufortian package locally decreases to about 1,600 ft under the fold and thrust belt of the Brooks Range foothills.

In addition to the Mississippian basins, the central part of the study area is also traversed by the north-south trending Meade arch (fig. 1) and the eastern flank of the Colville high, which is located just to the east of the NPRA. Both of these highs cause thinning or truncation of the Ellesmerian sequence (primarily the Endicott and Lisburne Groups) and the Beaufortian sequence (Kingak Shale).

The west-northwest trending Carbon Creek fault zone, inferred to be a strike-slip fault, traverses southern NPRA from south-central NPRA to the western boundary of NPRA. This steeply dipping zone is characterized by an absence of reflections within the zone, and apparent offset of stratigraphic reflectors across the zone. It is visible on numerous regional seismic lines.

\section{Thrust Fault Interpretations}

The south ends of all of the north-south oriented regional seismic lines, and the east-west lines that are in southern NPRA (R-17, R-18, R-20) traverse the northern part of the Brooks Range orogen, where Tertiary thrust faults underlie the foothills and southern part of the coastal plain (Moore and Potter, 2003; Potter and Moore, 2003). The quality of the seismic data in this region is fair to poor because of the strong deformation and the rugged topography, and considerable uncertainties exist in the identity of the main seismic-stratigraphic markers. For this reason, on most of the north-south seismic lines, we have terminated our interpretations of stratigraphic horizons near the north edge of the strongly deformed region. We have included extensive interpretations of thrust faulting on three regional seismic lines (R-1, R-6, and R-10), and we have partially interpreted the thrust faulting on other seismic lines, based on obvious criteria such as cutoff relations and ramp-flat geometry.

The south ends of lines R-7, R-8, R-9 and R-10 include thrusted and folded Brookian strata, above a regional detachment in the Kingak Shale (Potter and Moore, 2003). This detachment ramps up into Brookian strata in the northernmost part of the fold-thrust belt. The structural style is illustrated by the interpretation of the south end of R-10, in the Umiat area. Prominent anticlines in the Nanushuk Group overlie domains of local structural thickening in the Torok Formation. There is relatively little internal deformation beneath the intervening synclines, indicating that a regionally continuous roof thrust is not present in this area and that shortening is mainly dissipated upward within in each anticline. Farther north, the deformation front is marked by the tip of a very broad, low-amplitude, structurally-thickened welt of mud-rich Torok Formation above a 
detachment at its base. The Nanushuk Group is draped over the welt, forming a broad, subtle anticline (Potter and others, 2002; Potter and Moore, 2003).

Regional seismic lines west of (and including) R-19 extend farther south into the foothills belt, south of the frontal zones of thrusts and folds in the Brookian section, so that they include very complex thrust-faulting and folding of Ellesmerian, Beaufortian and Brookian strata. Such structures have been interpreted on R-1 and R-6. These thrust faults and folds are developed above a basal detachment that steps up from south to north, from the Mississippian Kayak shale, to Triassic Shublik Formation, the Jurassic Kingak Shale, and finally into Cretaceous Torok Formation. Thrust duplexes (Boyer and Elliot, 1982) stacked above this upward-stepping basal detachment are not uniformly well-imaged, but are readily apparent on some seismic lines, such as R-6. Tectonic wedging (Price, 1986) is a common structural style, particularly apparent in the interpretation of line R-6. A significant passive-roof duplex that is developed in the northern part of the foothills belt (Moore and others, 2002; Potter and others, 2003) is not well-imaged on the regional seismic lines included here.

Prominent antiformal thrust stacks are imaged near the south ends of R-6 and R-22; these are likely dominated by Endicott Group rocks of the Endicott Mountains allochthon (Mull, 1982; Moore and Potter, 2003; Potter and Moore, 2003). The southern parts of these seismic lines also cross poorly imaged, thrust-imbricated stacks of Lisburne Group of the Endicott Mountains allochthon, as well as higher allochthons. These allochthonous rocks of the southern foothills are in thrust contact above an autochthonous section at depth that is the southern continuation of the stratigraphy described in this report (Moore and Potter, 2003). The relatively undeformed autochthonous section is imaged on several of the regional seismic lines. The detachment level in the autochthonous section appears to be within the Kingak Shale.

\section{Summary}

In this study, new interpretations are provided for eight key stratigraphic horizons and structures in NPRA, based on a regional grid of reprocessed seismic lines. Each formation top and unconformity was interpreted using a combination of criteria, including lithology and proximal stratal geometry, in conjunction with picks from well logs. Over areas of obscure data, best fit picks were used.

The Ellesmerian sequence is poorly imaged in the southern part of the foothills belt, where highly deformed, allochthonous Ellesmerian rocks are present in the shallow part of the seismic sections, and a relatively undeformed autochthonous Ellesmerian sequence is present at depth. To the north, the Ellesmerian sequence is much more clearly imaged, and it thickens considerably beneath the northern foothills and southern part of the coastal plain, before thinning against the south flank of the Barrow arch due to Ellesmerian onlap of the former continental margin.

Locally within the Umiat and Meade basins, the Endicott and Lisburne Groups thicken dramatically. These basins appear to have originated as extensional basins. The configuration of the Umiat basin indicates reverse-fault reactivation of the northern basin-boundary fault.

The Beaufortian sequence is dominated by the southward prograding sedimentary sequences of the Kingak Shale. The pebble shale unit is distinguishable as a separate seismic event in the northern part of NPRA, and becomes seismically indistinguishable in the southern part.

Perhaps the most striking stratigraphic feature of the regional seismic lines is the transition from the southward-prograding Kingak Shale, below the LCU and pebble shale, to the northward and eastward prograding Brookian units above the pebble shale. The seismic expression of the 
Brookian is dominated by topset reflections of the Nanushuk and upper Torok Formations, passing into clinoforms of the Torok Formation. In southern NPRA, the lower Torok Formation consists of thick sections of subhorizontal reflections that are commonly involved in Tertiary-aged folding (Potter and Moore, 2003).

Although the data quality deteriorates significantly south of line R-20, antiformal stacks and passive-roof thrust fault geometries and folding have been interpreted beneath the southern foothills on several of the north-south lines. A regional decollement ramps up from the Kingak Shale into the Brookian section; it resides the Kingak Shale beneath much of southern NPRA. Beneath the northern part of the foothills belt, anticlines in the Nanushuk Group overlie domains of local structural thickening in the Torok Formation. The deformation front lies at the north edge of a broad, low-amplitude, structurally-thickened welt of Torok Formation above a detachment in the Torok.

\section{References Cited}

Armstrong, A.K., and Bird, K.J., 1976, Carboniferous environments of deposition and facies, Artic Alaska, in Miller, T.P., ed., Symposium on recent ancient sedimentary environments in Alaska: Anchorage, Alaska Geological Society Symposium Proceedings, p. A1-A16.

Barnes, D.A., 2001, Sedimentology and stratigraphy of the Sag River Formation, northern NPRAlaska, ), in Houseknecht, D.W. (editor), 2001, NPRA CORE WORKSHOP - Petroleum Plays and Systems in the National Petroleum Reserve - Alaska: SEPM Core Workshop no. 21, p. 5788 .

Bird, K.J., 1987, The framework geology of the North Slope of Alaska as related to oil-source rock correlations, in Tailleur, I., and Weimer, P., eds., Alaskan North Slope geology: Bakersfield, California, Society of Economic Paleontologists and Mineralogists, Pacific Section, and Alaska Geological Society, Book 50, v. 1, p.121-143.

Bird, K.J., 1988a, Alaskan North Slope stratigraphic nomenclature and data summary for government-drilled wells, in Gryc, G., eds., Geology and exploration of the National Petroleum Reserve in Alaska, 1974 to 1982: U.S. Geological Survey Professional Paper 1399, p. 317-353.

Bird, K.J., 1988b, Structure-contour and isopach maps of the National Petroleum Reserve in Alaska, in Gryc, G., ed., Geology and exploration of the National Petroleum Reserve in Alaska, 1974 to 1982: U.S. Geological Survey Professional Paper 1399, p. 355-377.

Bird, K.J., 2001, Framework geology, petroleum systems, and play concepts of the National Petroleum Reserve-Alaska, in Houseknecht, D.W. (editor), 2001, NPRA Core Workshop Petroleum Plays and Systems in the National Petroleum Reserve - Alaska: SEPM Core Workshop no. 21, p. 5-17.

Bird, K.J., and Houseknecht, D.W., 2002, U.S. Geological Survey 2002 petroleum resource assessment of the National Petroleum Reserve in Alaska (NPRA): U.S. Geological Survey Fact Sheet 045-02, http://pubs.usgs.gov/fs/2002/fs045-02/. 
Boyer, S.E., and Elliot, D., 1982, Thrust systems: American Association of Petroleum Geologists Bulletin, v. 66, p. 1196-1230.

Brosgé, W.P., Dutro, J.T., Jr., Mangus, M.D., and Reiser, H.N., 1962, Paleozoic sequence in eastern Brooks Range, Alaska: American Association of Petroleum Geologists Bulletin, v. 46, p. 2,174-2,198.

Campbell, R.H., 1967, Areal geology in the vicinity of the Chariot site, Lisburne Peninsula, northwestern Alaska: U.S. Geological Survey Professional Paper 395, 71 p.

Crowder, A.L., 1990, Permian and Triassic sedimentation in the northeastern Brooks Range, Alaska: deposition of the Sadlerochit Group: American Association of Petroleum Geologists Bulletin, v. 74, p. 1351-1370.

Grantz, Arthur, May, S.D., and Hart, P.E., 1990, Geology of the Arctic continental margin of Alaska, in Grantz, Arthur., Johnson, L., Sweeney, J.F., eds., 1990a, The Artic ocean region: Boulder, Colorado, Geological Society of America, The Geology of North America, V.L, 257288.

Gryc, George, 1985, The National Petroleum Reserve in Alaska, Earth-Science Considerations: U.S. Geological Survey Professional Paper 1240-C, 94 p.

Houseknecht, D.W., 2001, Sequence stratigraphy and sedimentology of Beaufortian strata (Jurassic - Lower Cretaceous) in the National Petroleum Reserve - Alaska (NPRA), in Houseknecht, D.W. (editor), 2001, NPRA Core Workshop - Petroleum Plays and Systems in the National Petroleum Reserve - Alaska: SEPM Core Workshop no. 21, p. 57-88.

Houseknecht, D.W., and Schenk, C.J., 2001, Depositional sequences and facies in the Torok Formation, National Petroleum Reserve - Alaska (NPRA), in Houseknecht, D.W. (editor), 2001, NPRA Core Workshop - Petroleum Plays and Systems in the National Petroleum Reserve Alaska: SEPM Core Workshop no. 21, p. 179-199.

Ikelman, J.A. (editor), 1986, Catalog of Geological and Geophysical Data for the National Petroleum Reserve in Alaska - Key to Geophysical Records Documentation No. 16 (Revised Edition), National Geophysical Data Center, Boulder, Colorado, p. 24-25.

Keller, A.S., Morris, R.E., and Detterman, R.L., 1961, Geology of the Shaviovik and Sagavanirktok rivers region, Alaska: United States Geological Survey Professional Paper 303-D, p. 169-219.

Kirschner, C.E., and Rycerski, B.A., 1988, Petroleum potential of representative stratigraphic and structural elements in the National petroleum Reserve in Alaska, in Gryc, G., ed., Geology and exploration of the National Petroleum Reserve in Alaska, 1974 to 1982, U.S. Geological Survey Professional Paper 1399, p. 191-208.

Miller, J.J., Agena, W.F., Lee, W.L., Zihlman, F.N., Grow, J.A., Taylor, D.J., Killgore, M., Oliver, H.L., 2000, Regional seismic lines reprocessed using post-stack processing techniques: National Petroleum Reserve - Alaska (NPRA), United States Geological Survey Open File Report 00-286. 
Miller, J.J, Agena, W. F., Lee, M.W., Zihlman, F.N., Grow, J.A., Taylor, D.J., Killgore, Michele, and Oliver, H.L, 2001, Four regional seismic lines - National Petroleum Reserve - Alaska (Supplement to U.S. Geological Survey Open-File Report 00-286): U.S. Geological Survey Open-File Report 01-0337.

Molenaar, C.M., 1988, Depositional history and seismic stratigraphy of Lower Cretaceous rocks in the National Petroleum Reserve in Alaska and adjacent areas, in Gryc, G., ed., Geology and exploration of the National Petroleum Reserve in Alaska, 1974 to 1982, U.S. Geological Survey Professional Paper 1399, p. 593-621.

Molenaar, C.M., Bird, K.J., and Kirk, A.R., 1987, Cretaceous and Tertiary stratigraphy of northeastern Alaska, in Tailleur, I., and Weimer, P., eds., Alaskan North Slope geology, v. 2: Bakersfield, California, Society of Economic Paleontologists and Mineralogists, Pacific Section, and Alaska Geological Society, p.513-528.

Moore, T. E., and Potter, C.J., 2003, Structural Plays in Ellesmerian sequence and correlative strata of the National Petroleum Reserve, Alaska: U.S. Geological Survey Open-File Report 03-253, 58 p. http://geopubs.wr.usgs.gov/open-file/of03-253/

Moore, T.E., Potter, C.J., and O'Sullivan, P.B., 2002, Structural architecture of the central Brooks Range foothills, Alaska (abs.): American Association of Petroleum Geologists Bulletin, v. 86, no. 6, p. 1153.

Moore, T.E., Wallace, W.K., Bird, K.J., Karl, S.M., Mull, C.G., and Dillon, J.T., 1994, Geology of northern Alaska, in Plafker, G., and Berg, H.C., eds., The Geology of Alaska, v. G-1, p. 49-140.

Mull, C.G., 1982, Tectonic evolution and structural style of the Brooks Range, Alaska: an illustrated summary, in Powers, R.B., ed., Geological Studies of the Cordilleran Thrust Belt, vol. 1: Rocky Mountain Assoc. of Geologists, Denver, CO, p. 1-45.

Mull, C.G., Houseknecht, D.W., and Bird, K.J., 2003, Revised Cretaceous and Tertiary stratigraphic nomenclature in the Colville basin, northern Alaska: U.S. Geological Survey Professional Paper 1673. http://pubs.usgs.gov/pp/p1673/

Mull, C.G., Roeder, D.H., Tailleur, I.L., Pessel, G.H., Grantz, A., and May, S.D., 1987, Geologic sections and maps across the Brooks Range and Artic Slope to Beaufort Sea: Geological Society of America Map and Chart Series MC-28S, scale 1:500,000

Potter, C. J., and Moore, T.E., 2003, Brookian structural plays in the National Petroleum Reserve, Alaska: U.S. Geological Survey Open-File Report 03-266, 49 p. http://pubs.usgs.gov/of/2003/of03-266/

Potter, C. J., Moore, T.E., O'Sullivan, P.B., and Miller, J.J., 2002, Regional structural framework and petroleum assessment of the Brooks Range foothills and southern coastal plain, National 
Petroleum Reserve-Alaska (abs.): American Association of Petroleum Geologists Bulletin, v. 86, no. 6, p. 1157.

Price, R.A., 1986, The southeastern Canadian Cordillera: thrust faulting, tectonic wedging and delamination of the lithosphere: Journal of Structural Geology, v. 8, p. 239-254. 